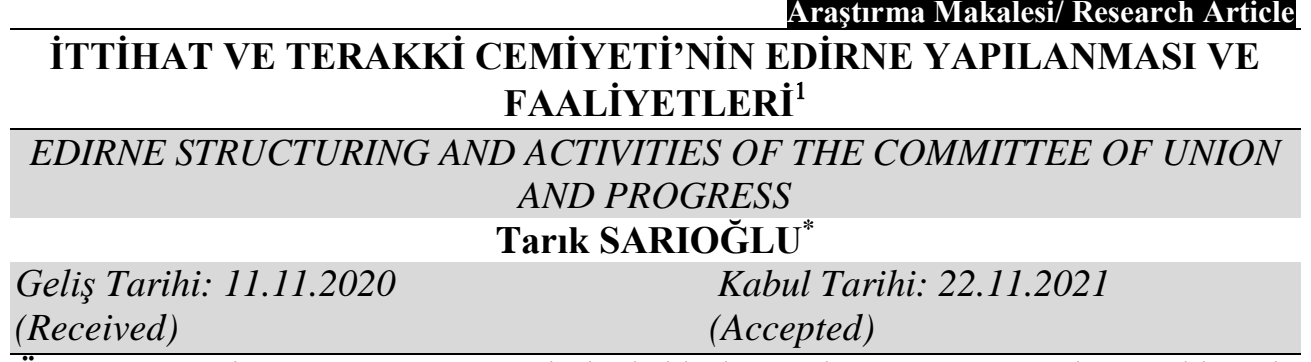

ÖZ: I. Meşrutiyet ve Kanun-1 Esasi’nin kaldırılmasından sonra Osmanlı topraklarında ortaya çıkan II. Abdülhamid karşıtı oluşumlar özellikle büyük şehirlerde yapılanmaya girişmişti. Payitahta yakınlığı, Balkanlardaki konumu ve İkinci Ordu'nun merkezi olması hasebiyle Edirne İttihatçılar için önemli bir şehirdi. 1889 yılından itibaren yurt içinde ve yurt dişında birçok şube açan İttihat ve Terakki Cemiyeti'nin hedeflerinden biri de askeri bir merkez olan Edirne'de II. Abdülhamid'e karşı girişilecek faaliyetleri destekleyecek bir grup oluşturmaktı. II. Abdülhamid'e karşı başlatılacak bir harekette ordunun silah gücünün önemi bilinmekteydi. Cemiyet, İstanbul'a yakın bir askerî gücün tam olarak desteği alınmadan merkezi otoriteye karşı başarı kazanılmasının zor olduğu düşünmekteydi. $\mathrm{Bu}$ doğrultuda şehirde taraftar bulmak amacıyla teşkilatçılığı ile ön plana çıkmış isimler Edirne'ye gönderilmeye başlanmıştı. Bir taraftan Edirne'deki subaylarla irtibata geçilerek askerî güç sağlanmış, diğer taraftan şehirde bağlantıları güçlü olan önemli isimler cemiyete kazandırılarak taraftar toplanmıştır.

Anahtar Kelimeler: İttihat ve Terakki Cemiyeti, Edirne, Edirne Grubu, II. Meşrutiyet

ABSTRACT: After the First Constitutional Monarchy and the abolition of the Constitution, the formations against II. Abdulhamid had started to restructure especially in big cities. Edirne was an important city for the Unionists due to its proximity to the capital, its location in the Balkans and being the center of the Second Army. One of the goals of the Committee of Union and Progress, which has opened many branches in the country and abroad since 1889, is in Edirne, a military center. It was to create a group that would support activities to be undertaken against Abdulhamid. The importance of the army's weapon power in an action to be launched against II. Abdulhamid was known. The Society considered it difficult to achieve success against the central authority without the full support of a military force close to Istanbul. In this direction, names that came to the fore with their organizational activities were sent to Edirne in order to find supporters in the city. On the one hand, military power was provided by contacting the officers in Edirne, on

${ }^{1}$ Bu makale, Dr. Öğr. Üyesi Bülent AKYAY danışmanlığında 2020 yılında tamamlanan, “II. Meşrutiyet'in İlanından Balkan Savaşları'na Kadar Edirne (1908-1912)” adlı doktora tezinden yola çıkarak hazırlanmıştır.

* Öğr. Gör. Dr., Trakya Üniversitesi, tariksarioglu@ trakya.edu.tr, ORCID: 0000-0003-12233517. 
the other hand, important names with strong connections in the city were brought to the society and supporters were gathered.

Key Words: The Committe Of Union And Progress, Edirne, Edirne Group, The Second Constitutional Era

\section{EXTENDEND ABSTRACT}

After the end of the First Constitutional Period and the abolition of the Kanun-i Esasi, both in Europe and in the Balkans secret societies had begun to be established against the II. Abdülhamid administration. Although these societies act independently of each other, their most important goals are it was to depose II. Abdulhamid, put the constitutional system back into effect and implement the Kanun-i Esasi. One of these societies was the society founded in 1889 by the students of the Military Medical School under the name of "Itttihad1 Osmanî" and later known as the "Ottoman Union and Progress Society (Osmanli Ittihat ve Terakki Cemiyeti)". The society started to expand in a short time with the participation of high-level bureaucrats and became stronger with the cell-like formations in other military schools. The society, which carried out the initiatives known as the Young Turk (Jön Türk) movement against the II. Abdülhamid administration in great secrecy until 1895, has come to light from this date. Members of the Committee of Union and Progress, which operated domestically, began to be arrested and exiled since 1896.

The structuring of the Committee of Union and Progress in Edirne emerged with the investigations and arrests that started throughout the country since 1885. Hafiz İbrahim Efendi was one of the leading names of the first unionist organization in Edirne. He frequently came to Edirne, the headquarters of the Second Army from Istanbul, and started work for the society here. In particular, its target audience has been the military environment. He influenced the high-ranking officers and soldiers he met in the barracks area in Edirne and in the coffeehouses where the soldiers came, and invited them to join the unionist ranks. Hafiz İbrahim Efendi's aim was to train soldiers in the army on freedom, liberty and equality. He, soon started to increase its influence both among the army base and among the soldiers. According to Hafiz İbrahim Efendi, the smallest freedom movement to be undertaken in Edirne would be effective in Istanbul. He knew the importance of the army's weapon power in such a movement. He thought it would be difficult to achieve success against the central authority without support from within the army or the cooperation of at least part of it. Therefore, while establishing connections with the military on the one hand, he had strengthened the ties by contacting the officers on the other hand. Around him, Edirne Central Hospital Chief Physician Dr. Mehmed Bey, Physician of the Cavalry Regiment Dr. İsmail Bey, the Director of Civil Service School Behçet Bey, the Clerk of the Population Kaltakkıran Faik Bey, who would later become one of the deputies of Edirne, Necip Efendi, one of the customs officers, Cemal Corporal from the army, Şerafettin from the artillery officers and Talat Bey from the post administration clerks were included. The group formed by these names was later called the "Edirne Group". Edirne Group started to expand further with the participation of some soldiers and officers. Secret meetings and negotiations continued until the middle of 1895 . The organization has expanded considerably and has accelerated its activities to reorganize the society, which was dispersed in Istanbul recently. However, upon the notification of Mülazım Said Efendi, one of the members of the organization, investigations and arrests 
were initiated for the group named as a member of the Committee of Union and Progress. In this period, although the number of members of Edirne branch is not known exactly, it is seen that the number of members is quite high due to the large number of receipts of the aids collected for the society. After these arrests and investigations, Edirne branch has lost its connection with Rusçuk, which it is in contact with.

After the arrests between 1895-1897, there is no information about the activities of the association in Edirne until 1905. The reason for this was that former members of the association who were detained and operating in Edirne were prohibited from entering Edirne. During this period, the situation of the society was not seen well in Istanbul. These arrests, made in 1896-1897, slowed the pace of the movement and not much could be done in the meantime. After these arrests, the support of the society from Rumelia decreased.

Despite the collapse of the structuring in Edirne, the activities of the unionists accelerated in the early 1900s. The activities of the association in Edirne regained dynamism with the activities of the officers assigned to the Second Army Command in Edirne after 1905. Especially names such as İsmet Pasha, Kazım Pasha, Seyfi Pasha and Hüseyin Kadri were at the leaders of this organization. In the autumn of 1907, Refet Pasha, one of the officers of the Edirne Gendarmerie Regiment, was given the task of forming the organization in Edirne. At the same time, the activities of Ismet Pasha in Edirne enabled the society to gain power around the city again in this period.

On 23 July 1908 in Istanbul, II. Abdulhamid issued a will stating that he had put the Kanun-i Esasi into effect again. After these developments, the first news was met with caution in Edirne due to the existence of the detection organization. However, after the news from Western Rumelia, there was a dynamism in the city. Within a few days, the Second Army officers attended the festivities held for the declaration of constitutionalism with the people. On July 27, 1908, the streets were decorated for the celebrations of the constitutional monarchy and lantern processions were held in the dark. During the day, speeches were made in front of the Provincial Mansion, Town Hall and Garrison Command. On July 28, 1908, two Thessaloniki representatives of the Committee of Union and Progress, Erkan-1 Harp Captain Ruşeni Bey and Captain Ahmet Bey, came to Edirne and made heated speeches. These speeches were of a kind that would not please the soldiers loyal to the sultan and some people of Edirne. After a while, it triggered events that would last for a few days in Edirne. After the fiery speeches of Ruşeni Bey and the impulsive behavior of the unionist officers, some of the Second Army officers who were worried about II. Abdulhamid's life wanted to go to Istanbul and see the sultan. On August 3, 1908, a 350 person military delegation departed from Edirne to Istanbul to see the status of the sultan. Soldiers, after II. Abdulhamid's admission, they calmed down and declared that they were not against Kanun-i Esasi and were loyal to the sultan. The Unionists, on the other hand, issued a statement and stated that they shared the same feelings.

After the proclamation of the Second Constitutional Monarchy, rapid changes occurred in the administrative administration of Edirne. By the Unionists who came to Edirne, the governor and the Second Army commander were first asked to swear allegiance to the constitutional administration. It was reported that if they swore, they could remain in their posts, but their salaries would be cut. At the same time, it was declared that the main 
powers and responsibilities will be those to be assigned by the Committee of Union and Progress. In addition, various pressures were applied to administrative, judicial and civil servants in Edirne. In fact, a declaration was prepared about the killing of the military Pashas and civil servants working in the city, their names were written on thirty layers of paper and hung in the squares in Edirne. In Edirne, senior executives, especially the governor and the Second Army commander, were replaced in a short time.

\section{GIRIS}

II. Abdülhamid'in I. Meşrutiyet idaresini ve Kanun-1 Esasi'yi kaldırmasıyla birlikte Avrupa'da ve Balkanlarda gizli cemiyetler kurulmaya başlanmıştı. Osmanlı Devleti'nin bu sürecine damgasını vuran en önemli siyasî gelişme söz konusu cemiyetlerin yürüttüğ̈̈ Jön Türk hareketiydi. Jön Türk hareketinin fikrî aşamasının yürütülmesinde ise İttihat ve Terakki Cemiyeti etkiliydi. İttihat ve Terakki Cemiyeti, Askerî Tıbbiye Mektebi öğrencileri tarafından 3 Haziran 1889 tarihinde kurulmuştu. Bu öğrenciler arasında İbrahim Temo, Diyarbakırlı İshak Sükûti, Harputlu Abdullah Cevdet, Bakülü Hüseyinzade Ali ve Kafkasyalı Mehmed Reşit bulunmaktayd $1{ }^{1}$. Cemiyetin ilk adı "İttihad-1 Osmanî " olarak bilinmekle birlikte sonradan "Osmanlı İttihat ve Terakki Cemiyeti" olarak değiştirilmiştì . Tibbiye Mektebi'nde kurulan cemiyet, ilk zamanlarda taraftar edinmeye önem verdiği için hiçbir siyasi harekete girişmemişti ${ }^{3}$. Cemiyet, üst düzey bürokratların da katılımıyla genişlemiş, kısa zamanda diğer askerî mektepleri de etkisi altına alarak benzeri hücreler oluşturmuştu ${ }^{4}$.

Hareketin genç temsilcileri, her birine özel isimler vermek suretiyle ilk toplantılarını yapmışlardı. Bunlardan birincisine "Dörtler İçtimai" ve bunu izleyenlere ise "Hatab Kıraathanesi İçtimaları" denilmişti". 1889'da yapılan ve ilk içtimaî olarak anılan "İnciraltı Toplantısı"nda Ali Rüştü Efendi başkan, Şerafeddin Mağmumi Bey zabıt kâtibi, Asaf Derviş Bey ise kasadar olarak görevliydi ${ }^{6}$. Oniki kişinin katıldığı bu toplantı ilk toplantıdan 2-3 ay sonra düzenlenmişti. Bu toplantı

\footnotetext{
${ }^{1}$ M. Şükrü Hanioğlu, Bir Siyasal Örgüt Olarak Osmanl Ittihat ve Terakki Cemiyeti ve Jön Türklük (1889-1892), İletişim Yay. İstanbul 1989, s. 173; Ahmet Bedevi Kuran, Inkılap Tarihimiz ve İttihat ve Terakki, Tan Matbaası, İstanbul 1948, s. 61; Sina Akşin, Jön Türkler ve Ittihat ve Terakki, İmge Yay., Ankara 2006, s. 35.

${ }^{2}$ Tevfik Çavdar, Ittihat ve Terakki, İletişim Yay., İstanbul 1991, s. 19.

${ }^{3}$ M. Şükrü Hanioğlu, Bir Siyasal Düşünür Olarak Doktor Abdullah Cevdet ve Dönemi, Üçdal Neşriyat, Ankara 1981, s. 26.

${ }^{4}$ Tevfik Çavdar, Ittihat ve Terakki, s. 19.

${ }^{5}$ Ernest Edmondson Ramsaur, Jön Türkler ve 1908 İhtilali, (Çev. Nuran Ülken), Sander Yay., İstanbul 1972, s. 32.

6 İbrahim Temo, Ibrahim Temo'nun Ittihat ve Terakki Anılarl, (Yayına Haz. Bülent Demirbaş), Arba Yay., İstanbul 2000, s. 16.
} 
cemiyetin ilk toplantısı olarak kabul edilmiş, katılan üyelere görev dağılımları ve derecelendirmeleri yapılmıştı ${ }^{7}$.

1895-1896 yıllarında cemiyetin duyulması ile yurtiçi ve yurtdışı faaliyetleri de artmaya başlamıştı. Cemiyet kurucuları o dönemin şartlarına uygun bir de nizamname hazırlamıştı. Cemiyet, ilk beyannamesini Ermenilerin 30 Eylül 1895 tarihinde yaptıkları Babıâli yürüyüşünü takiben hazırlayarak İstanbul'un çeşitli semtlerine dağıtmıştı. Cemiyet, bu hareketi ile birlikte 5 Ekim 1895 günü ilk kez varlığını açığa vurmuş, bu tarihten sonra ilk tutuklamalar ve sürgünler gelmişti ${ }^{8}$.

İttihat ve Terakki Cemiyeti, 1895 yılından itibaren İstanbul'da, Paris'te ve Londra'da birden çok grup halinde faaliyetlerine devam etti. Büyük şehir ve kasabalarda bir teşkilatlanma çabasına girişmişti. Şehirler, on şubeden az yirmi şubeden fazla olmamak üzere bölüklere ayrılmıştı. Her bölük, heyet-i idarenin nezaretinde üçer kişiden oluşan bir heyet tarafindan yönetilmeye başlandı ${ }^{9} .1896$ yılı itibariyle Kıbrıs, Trabzon, Beyrut, İzmir, Selanik, Şam, Midilli, Trablusgarp, Rodos, Suriye, Bulgaristan ve Girit gibi yerlerde merkez şubeler açıldı. Bunlara ek olarak Adana, Edirne, Mersin, Erzurum, Humus, Ankara gibi mahalli örgüt birimleri oluşturuldu ${ }^{10}$. Edirne'de İttihat ve Terakki yapılanmasının ilk göstergeleri bu dönemden itibaren başlamaktadır.

\section{EDİRNE'DE İLK İCRAATLAR VE EDIRNE GRUBU'NUN KURULMASI}

İttihat ve Terakki Cemiyeti, 1889 yılında kurulmasına rağmen Edirne'deki çalışmaları ile ilgili bilgilere 1895 yılından itibaren rastlanmaktadır. Bunun muhtemel nedeni cemiyetin faaliyetlerinin bu tarihten itibaren açığa çıkmasıdır. 1895 'ten itibaren ülke genelinde başlayan soruşturmalar ve tutuklamalar cemiyetin Edirne yapılanmasını da ortaya çıkarmıştı. Edirne'deki ilk İttihatçı yapılanmanın önde gelen isimlerinden biri Hafız İbrahim Efendi idi. Her ne kadar İttihat ve Terakki Cemiyeti'nin kurucu unsuru olan Tibbiyeli'lerden olmasa da 1889'da yapılan ve ilk içtimai toplantısı olarak anılan İnciraltı Toplantısı'nda yer aldığı bilinmektedir ${ }^{11}$. Hafız İbrahim Efendi, sıklıkla İstanbul'dan İkinci Ordu karargâhı

${ }^{7}$ Ernest Edmondson Ramsaur, a.g.e., s. 32-33.

${ }^{8}$ Yuriy Aşatoviç Petrosyan, Sovyet Gözüyle Jön Türkler, (Çev. Mazlum Beyhan), Bilgi Yay., İstanbul 1974, s. 184; Ahmet Bedevi Kuran, Inkllap Tarihimiz..., s. 63.

9 "Bahaddin Şakir Bey’in Bıraktığı Vesikalara Göre İttihat ve Terakki Niçin Teşkil Etmişti?”, Milliyet, Tarihi Tefrika:1, 4 Nisan 1934, s. 2.

${ }^{10}$ M. Şükrü Hanioğlu, Bir Siyasal Örgüt Olarak..., s. 193-194.

11 “Tıbbiyeli ilk kurucular arasında olmamakla birlikte kısa zamanda teşekküle katılmıştl. Hatta ilk kurucuların Topkapı dışında, Mithat Paşa çiftliğinde (İnciraltı mevkiinde) yaptıkları daha geniş toplantıda İpekli İbrahim de bulunur..." Bkz. Şevket Süreyya 
olan Edirne'ye gelerek burada cemiyet için çalışmalar başlatmıştır. Hedef kitlesi özellikle askerî çevre olmuştur. Edirne'deki kışlalar bölgesi ve askerlerin geldiği kahvehanelerde tanıştığı üst rütbeli subay ve erleri etkileyerek onları İttihatçı saflarına katılmaya davet etmiştir ${ }^{12}$. İbrahim Temo, Hafız İbrahim Efendi'yi şöyle anlatmaktadır:

“...Ben, ilk defa medreselilerden Kosoval ve hürrivette mebus olan İbrahim Efendi'yi ve mülkiye mezunlarından Necip Draga'yl, Görice mebusu Şahin Kolunya'yl cemiyetimize soktum. Hafiz İbrahim Efendi, Edirne'de Ramazan hocalı̆̆ yaparken serbestçe nasihatte bulunması neticesi posta memurlarından Talat Bey'i de cemiyete aldr. Bu sebepten Talat da mürşidi, Hafiz İbrahim Efendi'yi çok severdi, bana karșl da muhabbeti vardl" ${ }^{13}$.

$\mathrm{Bu}$ faaliyetler değerlendirildiğinde Edirne'deki ilk icraatların İttihat ve Terakki'nin kurulmasından hemen sonra başlandığı sonucuna varılabilir. Aslen Arnavut olan ve sonradan Kosova'nın İpek bölgesinden mebus seçilecek olan Hafız İbrahim Efendi ${ }^{14}$, Edirne'de cer hocalığ ${ }_{1}^{15}$ yaptığ 1 sırada cemiyet için çalışmalar yapmıştır. II. Abdülhamid tarafından İstanbul'daki şubenin dağıtılmasından sonra Kosova'ya geçmiş, ancak burada etkili olamayacağını düşünerek tekrar Edirne'ye dönmüştür. Hafız İbrahim Efendi'nin amac1, ordu içindeki askerlerin özgürlük, hürriyet ve eşitlik konusunda eğitilmesini sağlamaktı. Bundan dolayı Ramazan ayı içerisinde Edirne'de verdiği bütün vaazlarda askerlerin gittiği camileri seçmişti. Genellikle küçük mahalle mescid ve camilerini seçmiş, böylelikle hem etkili olmuş, hem de çok dikkat çekmemişti. Hafız İbrahim Efendi, kısa sürede gerek ordu tabanı gerekse askerler arasında tesirini arttırmaya başlamıştı ${ }^{16}$. Hafız İbrahim Efendi'ye göre, Edirne'de girişilecek en küçük bir özgürlük hareketi İstanbul'da etkili olabilecekti. Böyle bir harekette ordunun silah

Aydemir, Makedonya 'dan Orta Asya'ya Enver Paşa, C. 1, Yükselen Yay., İstanbul 1970, s. 278.

12 a.g.e., s. 279.

13 İbrahim Temo, Ibrahim Temo'nun Ittihat ve Terakki Anılarl, (Yayına Haz. Bülent Demirbaş), Arba Yay., İstanbul 2000, s. 18.

${ }^{14}$ Edirne'de Arnavut hoca diye bilinen İbrahim Efendi, küçük boylu, yamalı cübbesi ve kirli sarığı ile tanınmaktaydı. Bkz. Tevfik Çavdar, Bir Örgüt Ustasının Yaşam Öyküsü Talat Paşa, Kültür Bakanlığı Yay., Ankara 1995, s. 22; II. Meşrutiyetin ilanından sonra 1908'de açılan Meclis-i Mebusan'ın Merkez-i Umumî üyelerinden biri olarak da seçilmiştir. Bkz. Tarık Zafer Tunaya, Türkiye'de Siyasi Partiler, Ittihat ve Terakki, C. III, Hürriyet Vakfı Yay., İstanbul 1988, s. 21.

${ }^{15}$ Cerre Çıkma, eskiden medrese talebelerinin, mübarek üç aylarda köylere dağılıp halka, dini ögütlerde bulunmak, namaz kıldırmak veya müezzinlik etmek suretiyle para veya erzak toplaması usulüdür. Bkz. Ferit Devellioğlu, Osmanlıca-Türkçe Ansiklopedik Lûgat, Aydın Kitabevi Yay., Ankara 2014, s. 153.

${ }^{16}$ Tevfik Çavdar, Bir Örgüt Ustasının Yaşam Öyküsü Talat Paşa, s. 22. 
gücünün önemini bilmekteydi. Ordu içerisinden destek sağlanmadan ya da en az bir bölümünün işbirliği alınmadan merkezi otoriteye karşı başarı kazanılmasının zor olduğunu düşünmekteydi. Bundan dolayı bir taraftan asker ile bağlantı kurarken diğer taraftan subaylarla irtibata geçerek bağları güçlendirmişti ${ }^{17}$. Çevresinde Edirne Merkez Hastanesi Başhekimi Dr. Mehmed Bey, Süvari Alayı Tabibi Dr. İsmail Bey, Mülkiye İdadi Mektebi Müdürü Behçet Bey, daha sonra Edirne mebuslarından olacak olan Nüfus Kâtibi Kaltakkıran Faik Bey, gümrük memurlarından Necip Efendi, ordudan Cemal Onbaşı, topçu erlerinden Şerafettin ve Posta idaresi kâtiplerinden Talat Bey bulunmaktayd ${ }^{18}$. Bu isimlerin oluşturduğu grup sonradan "Edirne Grubu" adıyla anılmıştır. Midhat Şükrü Bleda hatıratında

"Talat Bey, o tarihlerde Edirne Postanesi”nde memurdu. Kalbi özgürlük için çarpıyor ve elinden geldiği kadarl ile bu davaya hizmetten kaçınmıyordu. Talat Bey'in Edirne'de iki yakın arkadaşı vardı. Faik Bey ve Ipekli Ibrahim Hoca. Aralarında yaptıkları görüşmeler ve toplantılar dikkati çekmişti” diyerek aralarındaki ilişkiden bahsetmiştir ${ }^{19}$.

İttihat ve Terakki'nin Edirne Grubu, Balkanlar'da uzun süredir faaliyet gösteren İbrahim Temo'nun faaliyetleri dışında hareket etmiş, Manastır merkezi vasıtasıyla Balkan teşkilatı ile irtibatı sürdürmüştü ${ }^{20}$. Yalnız Manastır'daki cemiyet faaliyetlerinin başarılı olmasına rağmen ilk aşamada Edirne'de aynı başarının olmadığı görülmektedir. Bunun en önemli nedenlerinin başında Edirne' de bulunan İkinci Ordu'nun kumanda kademesindeki subayların Üçüncü Ordu'dan daha genç ve tecrübesiz olması idi. Bir diğer nedeni ise bu subayların padişaha bağlılığının daha yoğun olmasıydı ${ }^{21}$.

Edirne gizli teşkilatının ilk aşamada Tuna kıyısındaki Rusçuk’ta kurulan bir merkez ile bağlantı kurduğu anlaşılmaktadır ${ }^{22}$. Çünkü Rusçuk'ta bulunan ve Talat Bey’in eniştesi olan İsmail Yürük Bey, sık sık Edirne'ye gelerek Paris'ten gelen gizli neşriyat hakkında bilgiler vermekteydi. Bir nevi Edirne’ye gelen bilgiler

${ }^{17}$ Hasan Babacan, Mehmet Talat Paşa (1874-1921), TTK Yay., Ankara 2014, s. 44; Tevfik Çavdar, Ittihat ve Terakki, s. 22-23; Şevket Süreyya Aydemir, Makedonya'dan Orta Asya'ya Enver Paşa, s. 279.

${ }^{18}$ Hasan Babacan, a.g.e., s. 44; Tevfik Çavdar, Ittihat ve Terakki, s. 22-23; Şevket Süreyya Aydemir, Makedonya'dan Orta Asya'ya Enver Paşa, s. 279.

${ }_{19}$ M. Şükrü Bleda, Imparatorluğun Çöküşü, Ittihat ve Terakki Katibi Umumisi, Remzi Kitapevi, İstanbul 1979, s. 20.

${ }^{20}$ M. Şükrü Hanioğlu, Bir Siyasal Örgüt Olarak..., s. 196.

${ }^{21}$ Tevfik Çavdar, Ittihat ve Terakki, s. 29.

${ }^{22}$ Bu merkez 1897'de Bulgaristan'ın Rusçuk bölgesinde cemiyetin Selanik merkezini kuranlardan Midhat Şükrü Bleda tarafından bir şube olarak kurulmuştu. Bkz. Şevket Süreyya Aydemir, Tek Adam Mustafa Kemal (1881-1919), C. I, Remzi Kitapevi, İstanbul 2011, s. 42. 
Rusçuk üzerinden sağlanmaktaydı ${ }^{23}$. Bu grup bazen Talat Bey’in evinin avluya bakan küçük odasında toplanır, İsmail Yürük Bey'in gönderdiği gazeteleri ve risaleleri okur, bazen de Talat Bey'in komşusu olan Faik Bey'in konağında toplanarak müzakereler yapardı. Edirne Grubu, bazı er, erbaş ve subayların katılımıyla daha da genişlemeye başlamıştı. Yapılan gizli toplantı ve müzakereler 1895 yılı ortalarına kadar devam etmişti. Teşkilat, oldukça genişlemiş ve kısa bir süre önce İstanbul'da dağıtılan cemiyetin tekrar teşkilatlanması için faaliyetlerini hızlandırmıştı ${ }^{24}$. Ancak teşkilat içinden biri olan Mülazım Said Efendi’nin ihbarı üzerine İttihat ve Terakki Cemiyeti üyesi olarak adlandırılan grup için soruşturmalar ve tutuklamalar başlatıld ${ }^{25}$. Bu tutuklamaları ve soruşturmaları İttihat ve Terakki yayın organları şöyle dile getirmişti:

“...Edirne'de eshab-ı hamiyyetden on yedi kişi tevkif olundu... Millet büyük zabitanımızdan satvet-i askerîyemizi, namus ve haysiyet milliyetimizi muhafaza edecek hidmetler beklerken bunların evladı hamiyyetli, namuslu zabitanımızın, hocalarımizin mahvina, koca ordumuzun bu devr-i mezalimde hissolunmayan perişaniyetine vasita oluyor. Tevkif olunan: iki mezun hoca, Mekteb-i Mülkiye idadisi müdürü, iki kitabet, on zabit, iki askerî tıbbiyelidir. Hele mevkufinden Arnavud Hoca İbrahim Efendi'yi bura ümerâ-yl askerîyesinden, Kosova vilayeti ahali-i mu'teberesinden, Arnavud Beylerinden, meşayihinden, hocadan hemen hemen tanımayani yoktur,26.

Edirne'deki asker ağılıklı bu şubenin çöküşü, cemiyet içinde yankı uyandırmıştı. Altı ay süren ilk soruşturmalardan sonra grup ikiye ayrılmıştı. Asker olmalarından dolayı Baştabip Mehmed, Doktor İsmail, Mülazım Ahmed Bey, Onbaşı Cemal, topçu neferi Şerafettin ve seyyar topçu neferi Abdullah'ın evrakı divan-1 harbe verilmişti. Sivil olanlar ise mahkemeye sevk edilerek şehir hapishanelerine gönderilmişti ${ }^{27}$. Çok sayıda askerî personelin tutuklanmasının yanı sıra Talat Bey, Faik Bey ve Mehmed Şeref Bey de tutuklananlar arasındaydı. Yine üstlerinde cemiyetin şifreli evrakı ve İttihatçı subaylar tarafından yazılmış sakıncalı belgeler ile yakalanan Hâver ve Necib adlarında iki genç subay tutuklanmıştı. Yapılan muhakemeler sonucunda İttihat ve Terakki isminde bir gizli cemiyet kurmaya teşebbüs eden Hafız İbrahim ceza kanunun 58. maddesi gereğince altı sene, bazı hafifletici sebeplerden dolayı diğerleri de üçer sene kalebentliğe mahkûm edilmişti. Talat Bey'in cezası Edirne İstinaf Mahkemesince onanmış, 30

${ }^{23}$ Şevket Süreyya Aydemir, Makedonya'dan Orta Asya'ya Enver Paşa, s. 279.

${ }^{24}$ Hasan Babacan, a.g.e., s. 44.

${ }^{25}$ Daha ayrıntılı bilgi için bkz. Tevfik Çavdar, Itttihat ve Terakki, s. 23-28.

${ }^{26}$ M. Şükrü Hanioğlu, Bir Siyasal Örgüt Olarak..., s.196-197; "Havadis-i Siyasiye", Meşveret, No: 20, H. 15 Mart 1896 / M. 1 Şevval 1313, s. 4; "Edirne'den", Mizan, No: 2, H. 23 Recep 1314 / M. 28 Aralık 1896, s. 4-5.

${ }^{27}$ Hasan Babacan, a.g.e., s. 44. 
Temmuz 1897 tarihinde memurluktan azledilerek Edirne Hapishanesine gönderilmişti ${ }^{28}$. Bu dönemde Edirne Şubesi'nin üye sayısı tam olarak bilinmemekle birlikte cemiyet için toplanan yardımların makbuz koçanlarının çokluğundan hareketle üye miktarının oldukça fazla olduğu görülmektedir. Bu tutuklama ve soruşturmalardan sonra Edirne Şubesi'nin irtibat halinde olduğu Rusçuk ile bağlantısı da kopmuştur ${ }^{29}$.

1895-1897 yılları arasında yapılan tutuklamalardan sonra 1905 y1lına kadar cemiyetin Edirne faaliyetleri ile ilgili bilgi bulunmamaktadir. Bunun nedeni Edirne'de faaliyet gösteren ve tutuklanan eski cemiyet mensuplarının Edirne'ye girişlerinin yasak olmasıydı ${ }^{30}$. II. Abdülhamid'in af ilanından sonra Edirne Hapishanesi'nde mahkûm bulunan Talat Paşa, Nüfus İdaresi Fransızca kâtibi Faik Bey, Mürefte Rüsumat Mubassırı Necib Bey ve Mitroviçe ahalisinden Hafız İbrahim Efendi için uygun bir iş bulunarak diğer vilayetlere gönderilmesi bildirilmişti $^{31}$. Bunun üzerine diğer mahkûmlar gibi İstanbul veya Edirne’ye bir daha gelmemeleri şartıyla salınan Hafız İbrahim Efendi, memleketi Mitroviçe’ye dönmüştü ${ }^{32}$. Talât Bey Selanik’te göz hapsinde bulundurulmuş, Faik Bey Konya'ya sürülmüştü ${ }^{33}$. Bu dönemde cemiyetin durumu İstanbul'da da parlak görülmemekteydi. 1896-1897 yıllarında yapılmış olan bu tutuklamalar hareketin hızını kesmiş ve aradan geçen zaman içinde pek bir şey yapılamamıştı. Bu tutuklamalardan sonra cemiyetin Rumeli kanadındaki destek azalmıştı ${ }^{34}$.

Rumeli bölgesinde İttihat ve Terakki yapılanmasının gelişmesinde Edirne'deki yapılanma önemli bir role sahipti. Cemal Kutay,

Prens Sebahattin, II. Abdülhamid, Ittihat ve Terakki adlı eserinde, "Ittihat ve Terakki Cemiyeti'nin Rumeli'ye yaylmasina en ziyade 'Edirne Grubu' ad verilen teşekkül sebep olmuştu ki, bunun başında da Talat Bey ve İpek Mebusu olan meşhur

28 a.g.e., s. 44-45.

${ }^{29}$ M. Şükrü Hanioğlu, Bir Siyasal Örgüt Olarak..., s.197.

${ }^{30}$ Edirne Hapishanesi'nde mahkumen tevkif bulunan Edirne Postahane kâtibesinden Talat, Nüfus İdaresi Fransızca Kâtibi Faik ve Mürefte Rüsumat Müdürü Necip ve Hafiz İbrahim nam şahsiyetleri af olunmuştur. Bkz. BOA, BEO., 1086/81433, (H. 10 Şevval 1315 / M. 4 Mart 1898); Talat Paşa, Edirne Hapishanesi'nde bir buçuk yıl kaldıktan sonra İstanbul'dan gelen bir hüküm ile affedilmiştir. Ancak Talat Paşa ve affedilen diğer cemiyet mensupları ne Edirne oturabilecek ne de İstanbul'a gidebileceklerdi. Talat Paşa, Selanik'i seçmiş, sonradan meşrutiyetin ilanında etkili olan teşkilatlanmayı da burada yapmıştır. Bkz. Şevket Süreyya Aydemir, Makedonya'dan Orta Asya 'ya Enver Paşa, s. 280.

${ }^{31}$ BOA, I.HUS, 62/22, (H. 8 Şaban 1315).

${ }^{32}$ Şevket Süreyya Aydemir, Makedonya'dan Orta Asya'ya Enver Paşa, s. 280.

${ }^{33}$ M. Şükrü Bleda, a.g.e., s. 20.

${ }^{34}$ Ernest Edmondson Ramsour, Jön Türkler ve 1908 Ihtilali, (Çev. Nuran Ülken), Sander Yay., İstanbul 1972, s. 152. 
Hafiz İbrahim Efendi ve Talat Paşa'nın eniştesi İsmail Yürük Efendiler vardl ${ }^{35}$ "diyerek bu görüşü desteklemiştir.

Edirne'deki yapılanmanın çöküşüne rağmen 1900'lü yılların başlarında İttihatçıların faaliyetleri hız kazandı. Bu dönemin önemli gelişmelerinden biri de Avrupa'da ve yurt içinde faaliyet yürüten İttihatçıların 4-9 Şubat 1902 tarihleri arasında "Osmanlı Liberaller Kongresi" adı altında Paris'te toplanmalarıyd1". Kongrenin ilk oturumu, Fransiz Akademisi üyelerinden Mösyö Leter Pountalis'in Paris'teki evinde yapılmıştı ${ }^{37}$. Kongrenin daha sonraki çalışmalarına ise Prens Sabahattin'in evinde devam edilmiști ${ }^{38}$. Kongreye; Ermeni, Rum, Arap, Arnavut, Kürt, Çerkez ve Musevi gruplarında iştiraki ile birlikte birçok delege katılmışt ${ }^{39}$. Prens Sabahattin başkanlığında Ahmed Rıza, Yusuf Akçura, İbrahim Temo, Halil Ganem, Selanikli Dr. Nazım, İsmail Kemal, İsmail Hakkı (Paşa), Hoca Kadri, Mahir Sait, Ferit Bey, Ali Haydar, Hüseyin Siret, Doktor Refik Nevzat gibi hareketin önde gelen isimleri de kongrede bulunmaktayd1 ${ }^{40}$. Bu kongre ile birlikte iki farklı cemiyet ortaya çıkmıştı. Birincisi, Prens Sabahattin'in desteklediği "Teşebbüs-i Şahsi ve Âdem-i Merkeziyet Cemiyeti ${ }^{41 ",}$ ikincisi ise Ahmed Rıza Bey'in desteklediği "Terakki ve İttihat Cemiyeti ${ }^{42}$ " idi.

${ }^{35}$ Cemal Kutay, Prens Sabahattin Bey, Sultan II. Abdülhamid, Ittihat ve Terakki, Tarih Müesseseleri Yay., İstanbul 1964, s. 223.

${ }^{36}$ Müfid Şemsi, Şemsi Paşa, Arnavutluk ve Ittihat-Terakki / El Hakku Ya'lû Vela Yû'lâ Aleyh, (Haz. Ahmed Nezih Galitekin), Nehir Yay., İstanbul 1995, s. 17; Tevfik Çavdar, Ittihat ve Terakki, s. 18-19; Ernest Edmondson Ramsaur, a.g.e., s. 83.

${ }^{37}$ Ahmet Bedevi Kuran bu ismi eserinde Mösyö Lafeuvre Contalis olarak vermiştir. Bkz. Ahmet Bedevi Kuran, Inkılap Tarihimiz ..., s. 182, 189.

38 Ernest Edmondson Ramsaur, a.g.e., s. 83; Prens Sabahattin, Türkiye Nasıl Kurtarlabilir?, (Çev. Muzaffer Sencer), Elif Yay., İstanbul 1965, s. 9; Ahmet Bedevi Kuran, Osmanlı İmparatorluğunda İnklap Hareketleri ve Millî Mücadele, İş Bankası Kültür Yay., İstanbul 2012, s. 254.

${ }^{39}$ Delegelerin sayısı ile ilgili farklı rakamlar bulunmaktadır. Ramsaur eserinde 47 olarak vermiş, Ahmet Bedevi Kuran, 60-70 civarında delege sayısından bahsetmektedir. Cemal Kutay da aynı rakamı vermiştir. Müfid Şemsi eserinde 40 sayısı verilmiştir. Yine, Sina Akşin'e göre ise sayı 40 civarındadır. Bkz. Ernest Edmondson Ramsaur, a.g.e., s. 84; Ahmet Bedevi Kuran, Inkılap Tarihimiz..., s. 347; Cemal Kutay, a.g.e., s. 144; Müfid Şemsi, a.g.e., s. 17; Sina Akşin, a.g.e., s. 66; Ahmet Eyicil, "Osmanlı İttihat ve Terakki Cemiyeti”, Türkler, C. XIII, Yeni Türkiye Yay., Ankara 2002, s. 410.

${ }^{40}$ Yuriy Aşatoviç Petrosyan, a.g.e., s. 217; Enver Ziya Karal, Osmanlı Tarihi, C. VIII, TTK. Yayınları, İstanbul 2007, s. 521.

${ }^{41}$ Ahmet Bedevi Kuran, Inkılap Tarihimiz..., s. 192; Tarık Zafer Tunaya, Türkiye'de Siyasi Partiler, II. Meşrutiyet Dönemi, C. I, Hürriyet Vakfi Yay., İstanbul 1988, s. 21.

${ }^{42}$ Ahmet Bedevi Kuran, Inkllap Tarihimiz..., s. 191; Tarık Zafer Tunaya, Türkiye'de Siyasal Gelişmeler, Kanun-ı Esasi..., C. 1, s. 21. 
Trakya Üniversitesi Sosyal Bilimler Dergisi

629

Aralı 2021 Cilt 23 Sayı 2 (619-640)

\section{II. MESSRUTIYYT ÖNCESİ EDİRNE'DE İKİNCİ YAPILANMA} ÇALIŞMALARI

Cemiyetin Edirne faaliyetleri 1905'ten sonra Edirne'deki İkinci Ordu Komutanlığı'na atanan subayların faaliyetleri ile birlikte tekrar hareketlilik kazandı. Özellikle İsmet Paşa (İnönü), Kazım Paşa (Karabekir), Seyfi Paşa (Düzgören), Hüseyin Kadri gibi isimler bu teşkilatlanmanın başında idi ${ }^{43} .1907$ yılının sonbaharında Edirne Jandarma Alayı subaylarından Refet Paşa'ya Edirne'de örgütü oluşturma görevi verilmişti ${ }^{44}$. Aynı zamanda İsmet Paşa'nın Edirne'deki faaliyetleri bu dönemde tekrar cemiyetin şehir çevresinde güç kazanması sağlamışt1 ${ }^{45}$.

Nizamettin Nazif Tepedelenli bu konuda eserinde, "Edirne teşkilâtını kuranlar da İsmet (İnönü), Kâzım Karabekir (Paşa), Seyfi Bey (Paşa) ve Hüseyin Kadri oldular" "66; Kazım Karabekir ise, cemiyetin Edirne merkezinde, "I Ismet Inönü, General Seyfı Düzgören ve Hüseyin Kadri bulundular. Fethi Okyar da bir yll sonra tekrar Selanik'e tayin olunduktan sonra burada Terakki ve Ittihat Cemiyeti'ne girmiştir..." diyerek Edirne'deki bu yapılanmayı doğrulamıştır ${ }^{47}$. İsmet Paşa'nın da Edirne'deki faaliyetleri bu dönemde cemiyetin tekrar şehir çevresinde güç kazanması sağlamıştır. İsmet Paşa,

"Cemiyetin usulleri içinde, İttihat ve Terakki, artık Edirne'de de kurulmuş çalışıyordu. Fethi Bey ile emniyetle mektuplaşabilmek için kisa bir şifre tespit etmiştik. 'Padişah' kelimesi 'ihtilal' manasına; 'sadakat', 'meşrutiyet' manasına; 'ubudiyet' de 'hürriyet' manasina geliyordu. O zamanki zihniyetimize göre polise karşı tedbir almıștik ${ }^{48,}$ diyerek yapılanmanın gizliliği hakkında bilgi vermiştir ${ }^{49}$.

${ }^{43}$ Sina Akşin, a.g.e., s. 95; Nizamettin Nazif Tepedelenlioğlu, Illan-ı Hürriyet ve Sultan II. Abdülhamid Han, Yenimatbaa Yay., İstanbul 1960, s. 59; Kazım Karabekir, Ittihat ve Terakki Cemiyeti, Yapı Kredi Yayınları, İstanbul 2011, s. 91.

${ }^{44}$ Şevket Süreyya Aydemir, Ikkinci Adam (1884-1938), C. I, Remzi Kitapevi, İstanbul 2011, s. $42-43$.

45 “1907 sonbaharında Edirne’de yeni bir hayat başladl. Ittihat ve Terakki Cemiyeti'nin, üçüncü ordunun mıntıkasını teşkil eden Batı Rumeli'deki yayılması, Edirne bölgesine kadar uzanmıştır. Gizli cemiyet, vatanın tehlikede olduğunu ve Kanun-ı Esasi'nin iadesiyle devlet idaresinin düzelmesinden başka çare olmadı̆̆ını vatanseverlere bildiriyordu." Bkz. Ísmet Inönü'nün Hatıraları Genç Subaylı Yıllarım (1884-1918), (Haz. Sabahattin Selek), Yenigün Haber Ajans1 Yay., İstanbul 1997, s. 47.

${ }^{46}$ Nizamettin Nazif Tepedelenlioğlu, a.g.e., s. 59.

${ }^{47}$ Kazım Karabekir, a.g.e., s. 91.

48 İsmet İn̈nü’nün Hatıraları Genç Subaylık Yillarım (1884-1918), s. 47.

${ }^{49}$ Günümüze kadar varlığını koruyan Hafız Ağa Konağı, İttihat ve Terakki Cemiyeti'nin gizli toplantılar yaptığı bina olarak bilinmektedir. Kereste ve inşaat malzemesi 
1906-1907 y1llarına gelindiğinde Jön Türk Hareketi, Balkanlarda hareketlenmeye başlamışt ${ }^{50}$. Hareketin faaliyetleri, 1906 yılında "Osmanlı Hürriyet Cemiyeti” adıyla Selanik'te kurulan başka bir gizli cemiyetle hız kazanmıştı ${ }^{51}$. Bu cemiyet, çoğunluğu Üçüncü Ordu subaylarının oluşturduğu, 7'si subay olmak üzere 10 kişi tarafından kurulmuştu. Bu grup; Bursalı Mehmet Tahir Bey (1 nolu üye), Midhat Şükrü (Bleda), Selanik Askerî Rüştiyesi Fransızca Öğretmeni Binbaşı Naki (Yücekök), Erkan-1 Harp Yüzbaşısı Edip Servet (Tör), Yüzbaş1 ve Müşiriyet (Mareşal) yaveri Kazım Nami (Duru), Yüzbaşı Ömer Naci Bey, Yüzbaşı İsmail Canbolat, Yüzbaşı Hakkı Baha Bey, Selanik Posta ve Telgraf Başkâtibi Talat Bey ve Rahmi Bey'den oluşmaktaydı. Bu üyeler arasında bulunan ve Edirne Grubu'nu oluşturan Talat Bey, Rahmi Bey, İsmail Bey, Heyet-i Aliyye'yi kurmuş, bu heyet daha sonra Merkez-i Umumî adını almıştır' ${ }^{52}$. Üyeleri genellikle genç subaylardan oluşan Osmanlı Hürriyet Cemiyeti'nin Avrupa'daki harekete göre daha canlı ve işlevsel olacağ bilinmekteydi $^{53}$. Bu nedenle, İttihat ve Terakki Cemiyeti ile Osmanlı Hürriyet Cemiyeti ortak hareket etme kararı ald ${ }^{54}$. 27 Eylül 1907 tarihinde "Osmanlı Hürriyet" ve "İttihat ve Terakki" cemiyetlerinin birleşmesini saptayan bir metin hazırlandı ve iki cemiyet birleştirildi ${ }^{55}$. Bu vesileyle Selanik Şubesi, Paris Şubesi'nin geçmişten gelen tecrübesinden; Paris Şubesi ise Selanik Şubesi'nin hem teşkilatçılığ hem de genç subayların dinamizminden yararlanmıştı. Böylelikle cemiyetin Avrupa merkezi Paris, Osmanlı merkezi

Romanya'dan getirilen bu bina sahibinin asıl adı Hafiz Mehmet idi. Türk İslam Mimarisi'nin tipik bir örneği durumundaki bina Edirne Valiliği tarafından 2002 yılında onarılıp restore edilmiştir. Ahmet Usal, a.g.e., s. 108.

${ }^{50}$ Tevfik Çavdar, Ittihat ve Terakki, s. 22.

${ }^{51}$ M. Şükrü Bleda'nın hatıratına göre ilk toplantı yeri Selanik’te Beş Çınar Bahçesi idi. Bkz. M. Şükrü Bleda, a.g.e., s. 21; Necmettin Alkan, Selanik'in Yükselişi (Jön Türkler Abdülhamid'e Karşı 1908 İhtilali), Timaş Yay., İstanbul 2012, s. 59.

${ }^{52}$ Kazım Nami Duru, Ittihat ve Terakki Hatıralarım, Sucuoğlu Matbaası, İstanbul 1957, s. 13; Tarık Zafer Tunaya, Türkiye'de Siyasal Gelişmeler, Kanun-ı Esasi..., C. 1, s. 21-22; Sina Akşin, a.g.e., s. 92.

${ }^{53}$ Tevfik Çavdar, Bir Örgüt Ustasının Yaşam Öyküsü Talat Paşa, s. 62-63

54 Yuriy Aşatoviç Petrosyan, a.g.e., s. 217; Tarık Zafer Tunaya, Türkiye'de Siyasal Gelişmeler, Kanun-ı Esasi..., C. 1, s. 22.

55 Merkezi Paris olan Osmanlı Terakki ve İttihat Cemiyeti ile merkezi Selanik'te olan Osmanlı Hürriyet Cemiyeti, 19 Şaban 1325 / 27 Eylül 1907 tarihinden itibaren Osmanlı İttihat ve Terakki Cemiyeti namı altında âtiyüzzikir şerait ile ittihat etmiştir. Belgenin tamamı için bkz. Ahmet Bedevi Kuran, Inkılap Tarihimiz..., s. 238; Tarık Zafer Tunaya, Türkiye'de Siyasal Gelişmeler, Kanun-ı Esasi..., C. 1, s. 49-50; Ernest Edmondson Ramsaur, a.g.e., s. 142-143. 
Selanik olmak üzere tüm şubelerin faaliyetleri tekrar düzenlendi ${ }^{56}$. Cemiyet, Selanik'teki yapılanmasının ardından yeni şubelerin açılması amacıyla Üçüncü Ordu merkezi olan Manastır'da teşkilatlanmaya başladı. Bu konudaki ilk adımlar ise sonradan Harbiye Nazırı olan Enver Paşa tarafından atıldı. Bu dönemde Manastır'da birçok subay cemiyete üye olmaya başladı ${ }^{57}$. İttihat ve Terakki'nin Edirne Şubesi ise Manastır merkezi vasıtasıyla Balkan teşkilatı ile irtibatı sürdürdü ${ }^{58}$.

Bu gelişmeler ile birlikte 27-29 Aralık 1907 tarihleri arasında Paris’te Baron Velorme adında bir Fransız'in evinde Prens Sabahattin, Ahmed Riza ve Ermeni Taşnaksutyun Cemiyeti’nin başkanı Malûmyan başkanlığında "İkinci Osmanlı Liberaller Kongresi" yapıld1 ${ }^{59}$. Azınlık mensuplarının da bulunduğu bu kongrenin amacı ortak bir hedefte buluşmaktı ${ }^{60} .29$ Aralık gününe kadar 20 oturum yapmayı başaran İttihatçılar, çalışmalarını tamamlayarak bir bildiri yayınladı ${ }^{61}$. Bu bildiriye göre, II. Abdülhamid tahttan indirilecek ve meclis tekrar açılacaktı. Mevcut sistem değiştirilerek meşrutiyet ve meşveret sistemi yürürlüğe girecekti ${ }^{62}$. Genel bir ayaklanma çıkarılacak ve istibdat dönemi sona erdirilecekti ${ }^{63}$.

1907 sonu ve 1908 başlarında İttihat ve Terakki, teşkilatlanmaya önem verirken aynı zamanda istibdatı sona erdirecek veya olası bir ihtilal durumunda başarıya ulaştıracak silahlı kuvvetlerin (Edirne'deki İkinci Ordu gibi) desteğini kazanmak için çaba harcad1. Bu nedenle 2 Mart 1908 tarihli Dr. Baha Şakir ${ }^{64}$ ve

${ }^{56}$ Enver Ziya Karal, Osmanlı Tarihi, C. IX, TTK. Yay., İstanbul 2007, s. 14; Ahmet Eyicil, a.g.m., s. 416.

${ }^{57}$ Bunların içerisinde Kazım Bey (Karabekir), Resneli Niyazi Bey gibi genç, girişken ve dinamik subaylar başı çekmekteydi. Bkz. Tevfik Çavdar, Ittihat ve Terakki, s. 28.

${ }^{58}$ M. Şükrü Hanioğlu, Bir Siyasal Örgüt Olarak..., s. 196.

59 İbrahim Temo İttihat ve Terakki anılarında kongrenin 15 Ekim 1907'de Baron Velorme adında bir kişinin konağında toplandığını, kongrenin dört gün sürdüğünü belirtmiştir. Bkz. İbrahim Temo, a.g.e., s. 171; Ahmet Eyicil, a.g.m., s. 416; Ernest Edmondson Ramsaur, a.g.e., s. 144.

${ }^{60}$ Ernest Edmondson Ramsaur, a.g.e., s. 144.

${ }^{61}$ Bildiri hakkında ayrıntılı bilgi için bkz. Ahmet Bedevi Kuran, Inkılap Tarihimiz..., s. 290-296; Yuriy Aşatoviç Petrosyan, a.g.e., s. 260.

${ }^{62}$ Necmettin Alkan, a.g.e., s. 64; M. Şükrü Hanioğlu, "Genesis of the Young Turk Revolution of 1908”, Osmanlı Araştırmaları, S. 3, İstanbul 1982, s. 298.

${ }^{63}$ Yuriy Aşatoviç Petrosyan, a.g.e., s. 261-262.

${ }^{64} \mathrm{Bu}$ ismin tam yazımı muhtemelen Dr. Bahaeddin Şakir Bey’dir. Ahmet Rıza Bey'in belgeleri arasında bulunan Tunalı Ahmet Lütfi imzalı bir mektubun ikinci sayfasında İttihat ve Terakki kurucuları ve "JÖN TÜRKLER" başlığı altında geçen isimlerden biridir. Bkz. Ahmet Riza, Anılar, Cumhuriyet Yay., İstanbul 2001, s. 30-31. 
Hüsrev Sami imzalı ${ }^{65}$, Sami adında birine hitaben yazılmış Paris merkezinin bir mektubuna şöyle bir dipnot eklenmişti:

"Edirne taraflarında (ikinci ordu) teşkilata muvaffak olundu mu? Şayet olunmadl ise Hüsrev Sami Efendi'yi Krrcaali tarikiyle oraya ithal mümkündür. Bahusus biraderi ve rüfekay-ı mutemedisi İkinci Ordu dâhilinde bulunduğundan ve oraların ahval-i dahiliyye ve mevkiiyyesini laylkıyla tanıdlğından az zaman zarfinda muntazam teşkilata muvaffak olacağı memuldür...",66

Paris'ten Selanik'teki Merkez-i Umumîye gönderilen 8 Mart tarihli Dr. Baha Şakir ve Hüsrev Sami imzalı başka bir mektupta, Edirne'de İkinci Ordu içinde kurulacak teşkilat için Hüsrev Efendi'nin kardeşi Eyüp Efendi'ye başvurulursa işin kolaylaşacağı bildirilmekte ve İzmir Valisi Kamil Paşa'nın damadı olan hastane Başhekimi Dr. Faik Paşa'ya başvurulmasının faydasız olmayacağı yazılmışı ${ }^{67}$.

$\mathrm{Bu}$ tarihlerde Edirne'de cemiyet mensuplarının sayısı ile ilgili çok fazla bilgi bulunmamakla birlikte Enver Paşa hatıralarında Makedonya'da dağa çıkmadan önce belirttiği üzere

“...Haziran dokuzunda ${ }^{68}$; Merkez-i Umumi azâsl, kışla meydanına nazır evimizin en üst katındaki küçük odada, ictima etmişti. Burada, benim hareketim hakkinda karar verecektik. Bir saat kadar Edirne Heyet-i Merkeziyyesinden gelmis olan Erkân-ı Harb Kolağası Hayri Bey'le görüştüm. Edirne teşkilatı hakkında henüz kat'î ma'lûmâtımız yoktu. Verdiği ma'lûmâta göre, hemân kâffesi zâbit olmak üzere, Kırkkilise ve Edirne civarında, yetmiş kadar efrâd-ı cemiyyet vardl. Maa-mâfih, az zamanda terakki etmesi kuvvetli idi. Kendisine hâtırtmda olan bir şifre miftâhı (anahtarı) verdim. Ertesi gün Edirne'ye hareket edecekti ${ }^{69, "}$ diyerek yaklaşı olarak bir sayı vermiştir. Kırkkilise ve Edirne civarında yetmiş kadar cemiyet mensubu olduğunu belirtmiştir.

II. Meşrutiyet, İstanbul ile birlikte 23 Temmuz 1908'de Edirne'de de ilan edilmiştir. Bu suretle bilhassa Rumeli şehirlerinde ve Edirne'de genç subayların çoğunluğu teşkil ettikleri İttihat ve Terakki Cemiyeti'nin gizli merkezleri açığa çıkarak mülki idareyi fiilen kontrolleri altına almışlard ${ }^{70}$. Hatta The Times gazetesi partinin merkezinin yavaş yavaş Selanik ve Manastır'dan başkentle yakınlaşmak ve

${ }^{65}$ Ahmet Rıza Bey'in belgeleri arasında bulunan Tunalı Ahmet Lütfi imzalı bir mektubun ikinci sayfasında İttihat ve Terakki kurucuları ve Jöntürkler başlığı altında geçen isimlerden biridir. Hüsrev Sami Efendi olarak listede adı bulunmaktadır. Bkz. Ahmet Rıza, a.g.e., s. 30-31.

${ }^{66}$ Yusuf Hikmet Bayur, Türk Inkılabı Tarihi, C. I, Kısım I, TTK Yay., Ankara 1991, s. 144. ${ }^{6}$ a.g.e., s. 144.

${ }^{68}$ Bu tarih Rumî 9 Haziran 1324 tarihine denk gelmektedir. Miladi olarak 22 Haziran 1908 tarihidir.

${ }^{69}$ Enver Paşa, Enver Paşa'nın Anıları (1881-1908), (Haz. Halil Erdoğan Cengiz), İletişim Yay., İstanbul 1991, s. 90.

${ }^{70}$ Şevket Süreyya Aydemir, Ikinci Adam, s. 51. 
olayların daha iyi kontrol altına alınması için Edirne'ye doğru kaydırılmaya çalışıldığı iddiasında bulunmuştur ${ }^{71}$.

\section{II. MEŞRUTIYYT'IN İLANINDAN SONRA CEMIYETIN EDIRNE FAALIYYETLERI}

23 Temmuz 1908 tarihinde İstanbul'da II. Abdülhamid Kanun-1 Esasi'yi tekrar yürürlüğe soktuğuna dair bir irade yayınlamıştı. Bu gelişmelerden sonra hafiye teşkilatının varlığı nedeniyle ilk haberler Edirne'de ihtiyatla karşılanmıştı. Ancak Bat1 Rumeli'den gelen haberlerden sonra şehirde hareketlilik yaşanmaya başlamışt ${ }^{72}$. Birkaç gün içinde İkinci Ordu kurmayları halk ile birlikte her tarafta meşrutiyetin ilanı nedeniyle yapılan şenliklere katıldı. 27 Temmuz 1908'de Edirne'de meşrutiyet kutlamaları için sokaklar süslenmiş ve havanın kararmasıyla fener alayları düzenlenmişti. Gün içinde Vilayet Konağı, Belediye Binası ve Garnizon Kumandanlığı'nın önünde konuşmalar yapıldd ${ }^{73}$. 28 Temmuz 1908 tarihinde İttihat ve Terakki Cemiyeti'nin iki Selanik temsilcisi Erkan-1 Harp Yüzbașısı Rușeni Bey ve Yüzbașı Ahmet Bey, Edirne'ye gelerek ateșli konușmalar yapmışlard1 ${ }^{74}$. Bu temsilciler, Edirne Valisi Mustafa Ziver Bey ${ }^{75}$, İkinci Ordu kumandanı Ali Rıza Paşa ve yüksek rütbeli sivil idarecilerle görüşerek İttihat ve Terakki Cemiyeti'ne sadakat yemini etmelerini istemişlerdi ${ }^{76}$. Ordu içindeki İttihatçı genç subaylar devletin bütün memurlarını cemiyete davet etmiş, eski rejime hizmet eden ve meşrutiyete biat etmeyen memurlara imkân vermemişlerdi ${ }^{77}$.

Yüzbaşı Ruşeni Bey'in söylev ve nutukları padişaha sadık olan askerlerin ve bir kısım Edirne halkının pek hoşuna gitmeyecek türdendi. Bu konuşmalardan bir süre sonra Edirne'de birkaç gün sürecek olayların tetiklenmesine neden oldu ${ }^{78}$. Ruşeni Bey, istasyonda konuşma yaptığı sırada halktan bir grup, "Padişahım çok yaşa!" diye bağırınca, İttihatçı subaylar duruma müdahale ederek bu türden

71 “Turkey”, The Times, 1 Ağustos 1908, s. 7.

${ }^{72}$ İsmet Inönü'nün Hatıralarl Genç Subaylık Yıllarım (1884-1918), s. 53-54.

73 “Ífade", Yeni Edirne, No: 1, H. 1 Recep 1326 / M. 30 Temmuz 1908, s. 1.

${ }^{74}$ Bu konuşmaların tamamı için bkz. Yeni Edirne, No: 1, H. 1 Recep 1326 / M. 30 Temmuz 1908, s. 1-2.

${ }^{75}$ Mustafa Ziver Bey bir gün sonra Zabtiye Nazırı Hayri Bey’in azledilmesinden dolayı Edirne Valiliği'nden alınarak Zabtiye Nazırı olarak atanmıştır (31 Temmuz 1908). Bkz. BOA, I.ZB., 3/48, (H. 2 Recep 1326 / M. 31 Temmuz 1908).

${ }^{76}$ Aykut Kansu, 1908 Devrimi (Elusive Transformation: The Revolution of 1908 in Turkey), (Çev. Ayda Erbal), İletişim Yay., İstanbul 1995, s. 135.

77 Ísmet Inönü'nün Hatıraları Genç Subaylık Yıllarım (1884-1918), s. 54.

78 Ayrıntılı bilgi için bkz. Serkan Yazıcı, "Edirne Ayaklanması", Uluslararası Edirne'nin Fethinin 650. Yıldönümü Sempozyumu Bildiriler Kitabı, 4-6 Mayıs 2011, T.Ü. Edebiyat Fakültesi Tarih Bölümü, Edirne 2012. 
sloganların atılmasının sona ermesini istemişlerdi. Ayrıca meşrutiyetin padişahın arzusuyla değil, İttihat ve Terakki Cemiyeti'nin mücadelesiyle ilan edildiğini tekrarlayarak kontrolü sağlamaya çalışmışlard ${ }^{79}$. Subayların istasyon duvarlarında asılı olan padişahı öven afişleri indirmelerinden sonra 32 y1llık II. Abdülhamid idaresini eleştiren konuşmalar yapılmaya devam edilmişti ${ }^{80}$.

Ruşeni Bey'in ateşli konuşmaları ve İttihatçı subayların fevri davranışlarından sonra II. Abdülhamid'in hayatından endişelenen İkinci Ordu subaylarından bazıları İstanbul'a gitmek ve padişahı görmek istemişlerdi ${ }^{81}$. 3 Ağustos 1908 tarihinde 350 kişilik bir askerî heyet padişahın durumunu görmek amaciyla Edirne'den İstanbul'a hareket etti ${ }^{82}$. Askerler, II. Abdülhamid'in

79 Ísmet Inönü’nün Hatıralarl Genç Subaylık Ylllarım (1884-1918), s. 56; Ernest Edmondson Ramsour, a.g.e., s. 151-152.

${ }^{80}$ Kazım Karabekir, Ittihat ve Terakki Cemiyeti adlı eserinde "Yapllan taklara (levha) o zamana kadar âdet olan, 'Padişahım Çok Yaşa' levhaları da konmuş. Ruşeni bu parlak merasimden heyecanlanarak büsbütün çileden çıkmış ve kılıcını çekerek bağırmış: Bu menhus (kötü) levhalar hâlâ burada neden asılı duruyor! Biz onu şöyle yaptık, böyle yaptık!., diye söylediğinin sonradan dahi farkına varmadan kılıcı ile bu levhaları parçalamış!’” şeklinde durumu beyan etmiştir. Bkz. Mizancı Mehmed Murad, Hürriyet Vadisinde Bir Pençe-i İstibdad, Nehir Yay., İstanbul 1997, s. 130; Kazım Karabekir, a.g.e., s. 226; "Turkey", The Times, Issue 38714, 1 Ağustos 1908, s. 7; "Le Mécontentement a Andrinople”, Le XIXe siècle, No: 14024, 3 Ağustos 1908, s. 2.

81 “Turkey", The Times, Issue 38713, 31 Temmuz 1908, s. 9; "Adrianople Garrison”, The Times, Issue 38716, 4 Ağustos 1908, s. 5.

${ }^{82}$ II. Abdülhamid'in eski Mabeyn Başkâtibi Tahsin Paşa hatıratında, “...Edirne'den asker müracaat ediyor, Hattı hümayunun ikinci mabeyinci Nuri Paşa götürsün Sadrazama malumat veriniz. Usulen lazım gelen şeyler yapılsın, emrini verdi. Tertibat yapıldı, Nuri Paşa da hattı alarak Babıâli'ye gitti. Telgrafhaneye gittim, askerin müracaatını istizah eyledim. Hünkârı görmek, Istanbul'a gelmek istediklerini söylediler, Edirne mühim yerdir, orasını bırakıp Ístanbul'a gelmek doğru değildir maksat ne ise söyleyiniz. Padişaha arz edeyim diye telgrafla cevap verdim. Telgrafhanenin içi dışı dolmuş, trenlere binip gelmeğe hazırlanmış oldukları anlaşıllyor. Hünkârın tehlikede olduğunu işittik, gibi birtakım sözlerle gelmek için israr ediyorlard. Hepsinin gelmekten vazgeçirilmesini taraflarından bir kısım efrat göndermelerini ve bu veçhile kismen ve murahhasan gelmelerini emretti. Trenle bir kısım asker geldi..." diyerek süreci anlatmıştır. Bkz. Tahsin Paşa, Tahsin Paşa, Abdülhamid ve Yıldız Hatıraları, Muallim Ahmet Halit Kitaphanesi, İstanbul 1931, s. 274; “...Yaklaşık 5000 kişi ve kadı, subaylar ve Genç Türk komitelerinin başkanlarının çabalarına rağmen istasyona ulaştılar ve sonucunda başkente 300 kişilik bir heyet göndermeye karar verdiler. Majestelerinin güvenliğinden emin olmak için saraya gönderildiler ve dün vardılar. Selanik İttihat ve Terakki Cemiyetinin üyelerinden oluşan başka bir heyet hükümet ile görüşmek için buraya geldiler. Bkz. "Adrianople Garrison", The Times, Issue 38716, 4 Ağustos 1908, s. 5; Dün öğleden sonra, muazzam bir kalabalık, Edirne İkinci Ordu Kolordusunun bir heyetini getiren özel tren istasyonuna gelmesi 
huzuruna kabulünden sonra sakinleşerek Kanun-1 Esasi’ye karşı olmadıklarını, padişaha bağlı olduklarını beyan etmişlerdi. İttihatçılar ise bir bildiri yayımlayarak kendilerinin de aynı duyguları paylaştıklarını ifade etmişlerdi ${ }^{83}$.

II. Meşrutiyet'in ilanından sonra Edirne'nin mülkî idaresinde hızlı değişiklikler meydana geldi. Edirne'ye gelen İttihatçılar tarafından ilk olarak vali ve İkinci Ordu komutanından meşrutî idareye bağlılık yemini etmeleri istendi. Yemin ettikleri takdirde görevlerinde kalabilecekleri, ancak maaşlarında kesinti yapılacağı bildirildi. Aynı zamanda asıl yetki ve sorumlulukların ise İttihat ve Terakki Cemiyeti’nin görevlendireceği kişilerde olacağı beyan edildi ${ }^{84}$. Bunun yanı sıra Edirne'de idarî, adlî ve mülkî memurlara çeşitli baskılar yapıldı. Hatta şehirde görev yapan askerî paşalar ve mülkiye erkânı hakkında öldürülmeleri ile ilgili bir beyanname hazırlanarak adları otuz tabaka kâğıda yazılmış ve Edirne'de meydanlara asılmıştı ${ }^{85}$. Ayrıca İttihat ve Terakki Cemiyeti Edirne Şubesi tarafından

nedeniyle birkaç saat bekledi; ancak 300 askerden oluşan ve birkaç subaydan oluşan heyet, San Stefano (Yeşilköy) İstasyonu'ndaki banliyölerdeki trenden inip Beshiktasch (Beşiktaş) için özel bir buharlı tren istasyonuna indi. Bkz. "La députation d'Andrinople", Le XIXe siècle, No: 14026, 5 Ağustos 1908, s. 2.

${ }^{83}$ Paris'te yayınlanan 5 Ağustos 1908 tarihli Le XIXe Siècle gazetesi, İstanbul'a gelen heyet ile ilgili olarak, “Dün Edirne'den gelen askerî heyet Beşiktaş’a gelerek, Savaş Bakanı ve Genel Sekreter Çakır Paşa tarafindan Yıldız Köşkü’ne götürüldü, burada Padişah subaylar ile akşam yemeği yedi. Padişah sonra bir pencereden kendini gösterdi. Heyeti komuta eden topçu komutanı Kadri Bey'i çağırdı ve ona; 'Hepinizi gördüğüm için çok mutluyum. Askerlerime, çocuklarıma değer veriyorum selamlarımı ve diğer ordu kollarındaki yoldaşlara göndermek için ücret (orduya dă̆ıtılması için) veriyorum'. Delegasyon, gelecek akşam Edirne'ye dönmek için ayrıldı..." şeklinde haberi ile gelişmeleri ayrıntılandırmıştır. Bkz. "La députation d'Andrinople", Le XIXe siècle, No: 14026, 5 Ağustos 1908, s. 2.

${ }^{84}$ Aykut Kansu, 1908 Devrimi, s. 141-142.

85 "Bursalı Cemal adındaki sınıf arkadaşımın evine gittim geceleyin, orada otuz tabaka kâğı üzerine beyanname yazdık. Altında İçtima ve Terakki Komitesi imzasını taşıyan bu el yazısı beyanname de Edirne'deki askerî paşalarla Mülkiye Erkânından öldürülmelerine karar verilenlerin adları sıralanmışt ....Sonra bu beyannameleri geceleyin sabahlara kadar dolaşarak Üç Şerefeli, Eski Camii, Zindanaltı, Selimiye v.s. gibi Edirne'nin meydanlarına çiriş ile yapıştırdım... Ertesi günü sabahleyin... Astığım beyannamelerin bazıları koparılmış alınmış, hala yerinde duranların etrafinda üç dört merakl durmuş okuyor... Fakat herkesin kafası o kadar karmakarışık ve hükümet o kadar şaşkın idi ki, bu işi meydana çıkarmayı kimse düşünemezdi...”, bkz. Rahmi Apak, Yetmişlik Bir Subayın Hatıraları, TTK Yay., Ankara 1988, s. 29-30, Edirne'de derin bir huzursuzluk hakim, çünkü liberallerin birlikleri işten çıkarma tarihi henüz belli değil. Duvarlarda, birkaç Ordu başkomutanı ve komiserin öldürmesini bildiren kartpostallar buldular. Bkz. "Le Mécontentement a Andrinople", Le XIXe siècle, No: 14019, 29 Temmuz 1908, s. 1; Kudret 
ildeki postane ofislerine, soruşturulmadıkça herhangi bir kişiye, kodlanmış telgraf gönderilmesine izin verilmemesi yönünde talimat verilmişti. Şube tarafindan " $b u$ karara karşı çıkmaya cesaret eden herkesin yerinde infaz edileceğ $i$ " bildirilmişti ${ }^{86}$.

Edirne'de vali ve İkinci Ordu komutanı başta olmak üzere idarî kademe bulunan üst düzey yöneticiler kısa sürede değiştirildi ${ }^{87}$. İlk olarak 8 Haziran 1907 tarihinden beri Edirne valisi olan Mustafa Ziver Bey'in görev yeri değiştirildi ${ }^{88}$. Mustafa Ziver Bey, 3 Ağustos 1908 tarihinde görevden alınarak yerine Selanik Valisi Hüseyin Nazım Paşa, Edirne Valiliği'ne tayin edildi ${ }^{89}$. Yalnız bu tayin üzerinden henüz bir hafta geçmemişken 10 Ağustos 1908 tarihinde Edirne Vilayet Valiliği' ne Siroz (Serez) Mutasarrıfı Reşit Paşa görevlendirilerek Hüseyin Nazım Paşa Cezayir-i Bahr-i Sefid Vilayeti'ne atand ${ }^{90}$. Reşit Paşa, meşrutiyetin ilan sürecinde Abdülhamid'e gönderdiği, "24 saat zarfinda meşrutiyet ilan edilmediği ve Kanun-ı Esasi yürürlüğe girmediği takdirde Siroz (Serez) Sancağının veliaht Reşad Efendi'ye biat edecektir..." şeklindeki telgrafı ile ün yapmışt1 ${ }^{91}$.

İttihat ve Terakki Cemiyeti, gerek idarî gerekse askerî memurları tensikat adı altında ya kontrole tabi tutmuş ya da görevlerine son vermişti. 1 Temmuz 1909 tarihinde "Tensikat Kanunu" ve buna ek olarak çıkarılan kanunlar ile binlerce memur görevden uzaklaştırıldı ${ }^{92}$. Bu doğrultuda Edirne vilayeti genelinde görevlerindeki yetersizlikleri ve kötü hallerinden dolayı emekliye sevk edilmesi veya değiştirilmesi istenilen memurlar hakkında bağlı bulundukları makamlarca gerekenin yapılması ile ilgili tebligat gönderildi. 28 Ağustos 1908 tarihli bu

Emiroğlu, Anadolu'da Devrim Günleri (II. Meşrutiyet İlanı Temmuz-A ğustos 1908), İmge Kitapevi, Ankara 1999, s. 132.

${ }^{86}$ M. Şükrü Hanioğlu, Preparation For A Revolution, The Young Turks, 1902-1908, Oxford University Press, New York 2011, s. 280.

87 “Turkey", The Times, Issue 38714, 1 Ağustos 1908, s. 7.

${ }^{88}$ BOA, BEO., 3072/230370; BOA, BEO., 3072/230371; BOA, BEO., 3072/230372, (H. 26 Rebiülahir 1325 / M. 8 Haziran 1907).

${ }^{89}$ BOA, BEO., 3368/252570, (H. 7 Recep 1326 / M. 5 Ağustos 1908); BOA, BEO., 3368/252571, (H. 6 Recep 1326 / M. 4 Ağustos 1908); BOA, DH.MKT., 1275/53, (H. 6 Recep 1326 / M. 4 Ağustos 1908).

${ }^{90}$ BOA, BEO., 3371/252757, (H. 12 Recep 1326 / M. 10 Ağustos 1908).

${ }^{91}$ Kudret Emiroğlu, a.g.e., s. 138.

${ }^{92}$ H. 12 Cemaziyelahir 1327 / M. 1 Temmuz 1909 tarihli, Tensikat Kanunu, Düstur, Tertib 2, C. 1, No: 2362, s. 326-332; Kamil Paşa'nın seçimler öncesinde 16 Ağustos 1908 tarihli hükümet programında da belirtilmiş ve buna göre devlet dairelerinde memur sayısı düşürülecek ve memurların aldıkları yüksek maaşlar azaltılacaktı. Bkz. "Turkish Reforms: Programme of the Ministry”, The Times, Issue 38727, 17 Ağustos 1908, s. 5; 1910 Mart ayında, Jön Türk hareketinden yirmi ay sonra, sefirlerin, valilerin tamamı, taşra müdürleriyle ticaret ataşelerinin çoğu değiştirilmişti. Değişim istatistikleri için bkz. M. Şükrü Hanioğlu, Preparation for a Revolution, The Young Turks, s. 287. 
tebligatta, yaşılı oldukları için görevlerinde yetersiz kalanlar emekliliğe sevk edildi. Aynı tebligatta görevlerini yapmayanların bulundukları nezarete isimlerinin bildirilmesi ve görevden uzaklaştırmalardan doğan memur sıkıntısının giderilmesi için tebligata cevap verilmesi istendi ${ }^{93}$.

\section{SONUÇ}

Edirne'deki İttihatçı yapılanma iki dönemi kapsamaktadır. Birinci dönem cemiyetin kurulmasından sonra faaliyetlerinin açığa çıkmaya başladığ1 1895-1897 yılları arasıdır. Ancak cemiyetin 1895 yılı öncesi faaliyetlerinin gizliliğinden dolayı Edirne'deki yapılanma daha eskiye götürülebilir. $\mathrm{Bu}$ dönemde İttihat ve Terakki'nin Edirne Grubu, Manastır merkezi vasıtasıyla Balkan teşkilatının bir parçası olan ve Rusçuk’ta kurulan bir merkez ile bağlantı kurduğu anlaşılmaktadır. Edirne'deki ilk yapılanma Hafız İbrahim Efendi öncülüğünde gerçekleştirilmeye çalışılmıştır. Talat Paşa, Kaltakkıran Faik Bey, Dr. Mehmed Bey, Dr. İsmail Bey, Behçet Bey, Necip Efendi, Onbaşı Cemal ve Şerafettin Bey, Edirne Grubu olarak anılan İttihatçı teşkilatlanmanın önemli isimleridir. 1896-1897 yıllarında başlayan tutuklanmalar sonucu bu grup dağıtılmış ve bu İttihatçılara çeşitli cezaların yanı sıra Edirne'ye giriş yasağı konulmuştur. Bu dönemde şehirdeki teşkilata katılan üye sayısı kesin olarak bilinmemekle birlikte soruşturmalar esnasında ele geçirilen cemiyetin yardım makbuzları dikkate alındığında üye miktarının aslında oldukça fazla olduğu görülmektedir. II. Abdülhamid'in İttihat ve Terakki Cemiyeti'ne karş1 aldığı çeşitli önlemler sonucu 1897 yılından 1905 yılına kadar şehirde herhangi bir İttihatçı faaliyete rastlanmamaktadır. Edirne'deki ilk İttihatçı yapılanma Manastır'daki gibi başarılı olamamıştır. İkinci Ordu'nun kumanda kademesindeki subayların Üçüncü Ordu'dan daha genç ve tecrübesiz olması, bu subayların padişaha bağlılı̆̆ının daha yoğun olması başarısızlığın nedenlerindendir.

Edirne'de cemiyetin tekrar yapılanmaya başladığı ikinci dönem ise 1905 yılından itibaren İkinci Ordu bünyesinde bulunan önemli subayların faaliyetlerini kapsamaktadır. Bu dönemde şehirde faaliyet gösteren İsmet Paşa, Kazım Karabekir, Seyfi Paşa, Refet Paşa ve Hüseyin Kadri Bey gibi isimler bu teşkilatlanmanın başındadır. Bu dönemdeki Edirne yapılanmasının Enver Paşa tarafindan örgütlenmiş olan Manastır Şubesi ile bağlantı kurduğu görülmektedir. II. Meşrutiyet'in ilanından sonra ülke genelindeki diğer şubeler gibi Edirne'de de genç subayların çoğunluğu oluşturduğu İttihat ve Terakki Cemiyeti'nin gizli merkezleri açığa çıkarak yönetimi fiilen kontrolleri altına almışlardır. Bu dönemde cemiyetin Edirne'deki ilk faaliyetleri şehir idarecilerinin kendilerine biat etmesini sağlamak, padişaha bağlı askerî ve mülkî memurları kontrol altında tutmak şeklindedir. Ancak kısa süre içinde bu yönetici kadroların birçoğu çeşitli vesileler ile görevden

${ }^{93}$ BOA, DH.MKT., 2615/57, (H. 28 Şaban 1326 / M. 25 Eylül 1908). 
alınarak İttihatçı idarecilerin göreve getirilmeleri sağlanmıştır. Edirne'de II. Meşrutiyet'in ilanı ilk aşamada ihtiyatla karşılansa da şehre gelen İttihatçı subaylar büyük bir çoşkuyla karşılanmıştır. Yalnız bu subayların II. Abdülhamid hakkındaki söylev ve nutukları Edirne'de bulunan İkinci Ordu mensubu bazı subayların hoşuna gitmemiş, 28 Temmuz-3 Ağustos 1908 tarihleri arasında şehirde bazı olayların patlak vermesine neden olmuştur. II. Abdülhamid'in hayatından endişe duyan İkinci Ordu subaylarının İstanbul'a giderek padişahı görmesi ile olaylar yatıştırılmıştır. $\mathrm{Bu}$ durum aynı zamanda Edirne'deki İkinci Ordu subay ve askerlerinin II. Abdülhamid'e daha sadık olduklarının göstergesidir.

Edirne'deki İttihatçı yapılanmanın ülke genelindeki İttihat ve Terakki Cemiyeti'nin güç kazanması ile doğru orantılı olduğu görülmektedir. Cemiyetin gizli faaliyetlerde bulunduğu ilk dönemlerinde çok fazla taraftar bulamasa da ikinci yapılanma süreci olarak değerlendirebileceğimiz 1905 yılı ve sonrası yapılanmanın öncekine göre daha aktif olduğu söylenebilir. Bunun en önemli nedeni ise 1905 yılından itibaren Selanik'te teşkilatlanan güçlü bir İttihatçı yapılanmanın etkisidir. Ayrıca meşrutiyetin ilanından sonra şehre atanan valilerin ve görevlilerin cemiyet mensubu kişilerden olması yapıyı güçlendirmiştir. 31 Mart Vakası'nın bastırılması amaciyla kurulmuş olan Hareket Ordusu'na, Edirne'deki askeri birliklerden de katılımin olması bu durumu destekler niteliktedir.

\section{KAYNAKÇA}

Ahmet Riza, Anılar, Cumhuriyet Yay., İstanbul 2001.

Akşin, Sina, Jön Türkler ve İttihat ve Terakki, İmge Yay., Ankara 2006.

Alkan, Necmettin, Selanik'in Yükselişi (Jön Türkler Abdülhamid'e Karşı 1908 İhtilali), Timaş Yay., İstanbul 2012.

Apak, Rahmi, Yetmişlik Bir Subayın Hatıraları, TTK Yay., Ankara 1988.

Aydemir, Şevket Süreyya, Makedonya'dan Orta Asya'ya Enver Paşa, C. 1, Yükselen Yay., İstanbul 1970.

Aydemir, Şevket Süreyya, Tek Adam Mustafa Kemal (1881-1919), C. I, Remzi Kitapevi, İstanbul 2011.

Aydemir, Şevket Süreyya, İkinci Adam (1884-1938), C. I, Remzi Kitapevi, İstanbul 2011.

Babacan, Hasan, Mehmet Talat Paşa (1874-1921), TTK Yay., Ankara 2014.

Bayur, Yusuf Hikmet, Türk Inkılabı Tarihi, C. I, Kısım I, TTK Yay., Ankara 1991.

Bleda, M. Şükrü, Imparatorluğun Çöküşü, İttihat ve Terakki Katibi Umumisi, Remzi Kitapevi, İstanbul 1979.

BOA, BEO., 3368/252570, 3368/252571, 3072/230370, 3072/230371, 3072/230372, 3371/252757.

BOA, DH.MKT., 1275/53, 2615/57.

BOA, I.HUS, 62/22. 
BOA, I.ZB., 3/48.

Çavdar, Tevfik, Itttihat ve Terakki, İletişim Yay., İstanbul 1991.

Çavdar, Tevfik, Bir Örgüt Ustasının Yaşam Öyküsü Talat Paşa, Kültür Bakanlığı Yay., Ankara 1995.

Devellioğlu, Ferit, Osmanlıca-Türkçe Ansiklopedik Lûgat, Aydın Kitabevi Yay., Ankara 2014.

Duru, Kazım Nami, Ittihat ve Terakki Hatıralarım, Sucuoğlu Matbaası, İstanbul 1957.

Emiroğlu, Kudret, Anadolu'da Devrim Günleri (II. Meşrutiyet İlanı Temmuz-A ğustos 1908), İmge Kitapevi, Ankara 1999.

Enver Paşa, Enver Paşa'nın Anıları (1881-1908), (Haz. Halil Erdoğan Cengiz), İletişim Yay., İstanbul 1991.

Eyicil, Ahmet, "Osmanlı İttihat ve Terakki Cemiyeti", Türkler, C. XIII, Yeni Türkiye Yay., Ankara 2002, ss. 404-436.

Hanioğlu, M. Şükrü, Bir Siyasal Düşünür Olarak Doktor Abdullah Cevdet ve Dönemi, Üçdal Neşriyat, Ankara 1981.

Hanioğlu, M. Şükrü, "Genesis of the Young Turk Revolution of 1908", Osmanlı Araştırmalart, S. 3, İstanbul 1982, ss. 276-300.

Hanioğlu, M. Şükrü, Bir Siyasal Örgüt Olarak Osmanlı İttihat ve Terakki Cemiyeti ve Jön Türklük (1889-1892), İletişim Yay. İstanbul 1989.

Hanioğlu, M. Şükrü, Preparation For A Revolution, The Young Turks, 1902 1908, Oxford University Press, New York 2011.

İbrahim Temo, İbrahim Temo'nun İttihat ve Terakki Anılarl, (Yayına Haz. Bülent Demirbaş), Arba Yay., İstanbul 2000.

İsmet Inönü'nün Hatıraları Genç Subaylık Yillarım (1884-1918), (Haz. Sabahattin Selek), Yenigün Haber Ajans1 Yay., İstanbul 1997.

Kansu, Aykut, 1908 Devrimi (Elusive Transformation: The Revolution of 1908 in Turkey), (Çev. Ayda Erbal), İletişim Yay., İstanbul 1995. İstanbul 2011.

Karabekir, Kazım, Ittihat ve Terakki Cemiyeti, Yap1 Kredi Yayınları,

Karal, Enver Ziya, Osmanlı Tarihi, C. VIII, TTK Yay., İstanbul 2007.

Karal, Enver Ziya, Osmanlı Tarihi, C. IX, TTK Yay., İstanbul 2007.

Kuran, Ahmet Bedevi, Inkılap Tarihimiz ve Ittihat ve Terakki, Tan Matbaası, İstanbul 1948.

Kuran, Ahmet Bedevi, Osmanlı Imparatorluğunda İnklap Hareketleri ve Millî Mücadele, İş Bankası Kültür Yay., İstanbul 2012.

Kutay, Cemal, Prens Sabahattin Bey, Sultan II. Abdülhamid, Ittihat ve Terakki, Tarih Müesseseleri Yay., İstanbul 1964. 
Le XIXe siècle, No: 14019, 29 Temmuz 1908, s. 1; No: 14024, 3 Ağustos 1908, s. 2; No: 14026, 5 Ağustos 1908, s. 2.

Meşveret, No: 20, H. 15 Mart 1896 / M. 1 Şevval 1313, s. 4.

Müfid Şemsi, Şemsi Paşa, Arnavutluk ve Ittihat-Terakki / El Hakku Ya'lû Vela Yû'lâ Aleyh, (Haz. Ahmed Nezih Galitekin), Nehir Yay., İstanbul 1995.

Milliyet, Tarihi Tefrika:1, No: 3139, 4 Nisan 1934, s. 2.

Mizan, No: 2, H. 23 Recep 1314 / M. 28 Aralık 1896, s. 4-5.

Mizanc1 Mehmed Murad, Hürriyet Vadisinde Bir Pençe-i İstibdad, Nehir Yay., İstanbul 1997.

Ramsaur, Ernest Edmondson, Jön Türkler ve 1908 İhtilali, (Çev. Nuran Ülken), Sander Yay., İstanbul 1972.

Petrosyan, Yuriy Aşatoviç, Sovyet Gözüyle Jön Türkler, (Çev. Mazlum Beyhan), Bilgi Yay., İstanbul 1974.

Prens Sabahattin, Türkiye Nasıl Kurtarılabilir?, (Çev. Muzaffer Sencer), Elif Yay., İstanbul 1965.

Tepedelenlioğlu, Nizamettin Nazif, Illan-ı Hürriyet ve Sultan II. Abdülhamid Han, Yenimatbaa Yay., İstanbul 1960.

Tahsin Paşa, Abdülhamid ve Yıldız Hatıraları, Muallim Ahmet Halit Kitaphanesi, İstanbul 1931.

Tunaya, Tarık Zafer, Türkiye'de Siyasi Partiler, Ittihat ve Terakki, C. III, Hürriyet Vakfi Yay., İstanbul 1988.

Tunaya, Tarık Zafer, Türkiye'de Siyasi Partiler, II. Meşrutiyet Dönemi, C. I, Hürriyet Vakfi Yay., İstanbul 1988.

Tunaya, Tarık Zafer, Türkiye'de Siyasal Gelişmeler (1876-1938) Kanun-ı Esasi ve Meşrutiyet Dönemi, C.1, İstanbul Bilgi Üni. Yay., İstanbul 2003.

The Times, Issue 38713, 31 Temmuz 1908, s. 9; Issue 38714, 1 Ağustos 1908, s. 7; Issue 38716, 4 Ağustos 1908, s. 5; Issue 38727, 17 Ağustos 1908, s. 5.

Usal, Ahmet, Edirne Tarihi ve Kültürü, Edirne Vergi Dairesi Başkanlığı, Edirne 2006.

Yazıcı, Serkan, "Edirne Ayaklanması", Uluslararası Edirne'nin Fethinin 650. Yıldönümü Sempozyumu Bildiriler Kitabı, 4-6 Mayıs 2011, T.Ü. Edebiyat Fakültesi Tarih Bölümü, Edirne 2012, ss. 329-339.

Yeni Edirne, No: 1, H. 1 Recep 1326 / M. 30 Temmuz 1908, s. 1-2. 